DOI: $10.19195 / 0137-1134.106 .20$

DARIUSZ WYKRENT

Uniwersytet Wrocławski

\title{
WYBRANE ASPEKTY PRAWNE ZAPEWNIENIA BEZPIECZEŃSTWA IMPREZ MASOWYCH JAKO JEDNEGO Z WARUNKÓW BEZPIECZEŃSTWA PUBLICZNEGO
}

\section{WPROWADZENIE}

W języku polskim pojęcie „bezpieczeństwo” definiowane jest jako: stan niezagrożenia; pewność, że nic nie zagraża; stan pewności, spokoju, zabezpieczenia ${ }^{1}$. W tym znaczeniu bezpieczeństwo jest stanem, który daje poczucie pewności istnienia obecnego i przyszłego. Jest to jedna z podstawowych potrzeb człowieka oraz grup społecznych. Człowiek, grupa społeczna, państwo, organizacja międzynarodowa starają się oddziaływać na swoje otoczenie zewnętrzne i sferę wewnętrzną, by usuwać, a przynajmniej oddalać zagrożenia, eliminując własny lęk, obawy, niepokój i niepewność. Jedną z form tego oddziaływania realizowaną przez państwo, a także organizacje międzynarodowe, jest system prawa. Problematyka bezpieczeństwa imprez masowych jest ważnym elementem życia społecznego. Bezpieczeństwo imprez masowych jest częścią szerszego pojęcia, jakim jest bezpieczeństwo publiczne, które jest jednym z najważniejszych oczekiwań obywateli wobec państwa i jednocześnie jednym z najważniejszych zadań państwa wobec obywateli. Niniejszy artykuł przedstawia wybrane aspekty obowiązującego w Polsce porządku prawnego, odnoszące się ogólnie do złożonej problematyki bezpieczeństwa oraz szczególnie do specyficznego — ze względu na formy i cechy występowania — bezpieczeństwa imprez masowych.

\section{POJĘCIE BEZPIECZEŃSTWA PUBLICZNEGO I JEGO KONSTYTUCYJNE REGULACJE}

Wyróżnia się różne rodzaje bezpieczeństwa. Ze względu na zasięg wyodrębnia się bezpieczeństwo globalne, międzynarodowe, narodowe, regionalne, lokalne.

${ }^{1}$ Stownik języka polskiego, red. W. Doroszewski, Warszawa 1958-1969, http://doroszewski. pwn.pl/haslo/bezpiecze\%C5\%84stwo/. 
Ze względu na stosunek do terytorium państwa bezpieczeństwo jest zewnętrzne i wewnętrzne. Ze względu na dziedzinę, w której występuje, może ono obejmować bezpieczeństwo publiczne, ekonomiczne, fizyczne, ekologiczne, socjalne, militarne, kulturowe, informatyczne itp. ${ }^{2}$

Bezpieczeństwo publiczne jest to ogół warunków i instytucji chroniących życie, zdrowie, mienie obywateli oraz majątek ogólnonarodowy, ustrój i suwerenność państwa przed zjawiskami zagrażającymi ładowi prawnemu, a także przed zjawiskami mogącymi zakłócić normalne funkcjonowanie obywateli, godzącymi w ogólnie przyjęte normy postępowania. Bezpieczeństwo publiczne jest także stanem w społeczeństwie, który umożliwia jego sprawne funkcjonowanie. Zagrożenia bezpieczeństwa publicznego mogą być zarówno wewnętrzne, jak i zewnętrzne, czyli mieszczą się tu ingerencje ze strony innych podmiotów państwowych w sprawy wewnętrzne, a także wewnętrzne konflikty i napięcia społeczne. Często przestępczość zakłóca ten ład, co rodzi w społeczeństwie poczucie niesprawiedliwości i braku kontroli państwa nad tym zjawiskiem oraz potrzebę wprowadzenia nowych regulacji prawnych zapobiegających tym zakłóceniom³ ${ }^{3}$.

Pojęcie bezpieczeństwa publicznego występuje w aktach normatywnych zarówno rangi ustawowej, jak i niższego rzędu. Należy jednak podkreślić, że pojęcie „bezpieczeństwo publiczne” nie zostało dotychczas w sposób precyzyjny określone w przepisach prawa. Ustawodawca w licznych przepisach posługuje się tym terminem, przy czym jego zakres jest bardzo często wieloznaczny. Stwarza to tym samym liczne niedogodności w procesie wykładni norm prawnych.

Przyjmuje się, że bezpieczeństwo publiczne to przede wszystkim zadanie publiczne organów administracji, ale może być też kryterium prawnym działania, kompetencją organu administracji rządowej lub samorządowej. Bezpieczeństwo publiczne jest przede wszystkim wartością konstytucyjną, w celu jej ochrony możliwe jest ograniczenie konstytucyjnych wolności i praw obywatela. Bezpieczeństwo demokratycznego państwa w kontekście art. 31 ust. 3 Konstytucji RP ${ }^{4}$ traktowane jest jako wartość wchodząca w skład interesu publicznego, jako ogólnego wyznacznika granic wolności i praw jednostki, przy czym nie należy tego interesu publicznego utożsamiać $\mathrm{z}$ interesem państwowym ani przeciwstawiać powinnościom jednostki. W świetle art. 5 Konstytucji RP bezpieczeństwo obywateli jest

2 Stownik terminów z zakresu psychologii dowodzenia i zarządzania, red. J. Borkowski et al., Warszawa 2000, s. 14.

3 Próby zestawienia definicji bezpieczeństwa publicznego podejmują autorzy w licznych publikacjach. Zob. Bezpieczeństwo wewnętrzne RP w ujęciu systemowym $i$ zadań administracji publicznej, red. B. Wiśniewski, S. Zalewski, Bielsko-Biała 2006, s. 29-32; B. Sprengel, Ustrój organów administracji bezpieczeństwa i porzadku publicznego, Włocławek 2004, s. 12; A. Misiuk, Administracja porzadku i bezpieczeństwa publicznego: zagadnienia prawno-ustrojowe, Warszawa 2008, s. 12-17; S. Pieprzny, Ochrona bezpieczeństwa i porzadku publicznego w prawie administracyjnym, Rzeszów 2007, s. 28-31.

${ }^{4}$ Ustawa z dnia 2 kwietnia 1997 r. Konstytucja Rzeczypospolitej Polskiej, Dz.U. 1997 Nr 78, poz. 483. 
podstawowym zadaniem państwa, w myśl zaś art. 230 Konstytucji RP bezpieczeństwo, a ściślej jego zagrożenie, jest konstytucyjną przesłanką wprowadzenia przez Prezydenta RP na wniosek Rady Ministrów, na czas oznaczony nie dłuższy niż dziewięćdziesiąt dni, stanu wyjątkowego na części lub całym terytorium państwa.

Oprócz pojęcia bezpieczeństwa publicznego Konstytucja RP przywołuje także pojęcie bezpieczeństwa państwa, które obejmuje bezpieczeństwo jego terytorium, władz i obywateli. W rozdziale VI Konstytucji RP poświęconym Radzie Ministrów i administracji rządowej ustrojodawca używa bowiem pojęcia „,bezpieczeństwo państwa". A zatem do kompetencji Rady Ministrów, która prowadzi politykę wewnętrzną i zagraniczną Rzeczypospolitej Polskiej, kieruje administracją rządową, należy zapewnienie bezpieczeństwa wewnętrznego i zewnętrznego państwa. Rada Ministrów w świetle Konstytucji RP jest odpowiedzialna przed Prezydentem, Sejmem i społeczeństwem za bezpieczeństwo obywateli w państwie.

Konstytucja RP wskazuje ponadto na możliwość ograniczenia konkretnych praw i wolności ze względu na ochronę bezpieczeństwa, tym samym pojęcie „bezpieczeństwo" występuje jako przesłanka ogólnego albo szczegółowego ograniczenia praw jednostkowych. Pojęcie to oznacza przesłankę wyłączenia jawności rozprawy sądowej (art. 45 ust. 2) oraz ograniczenia wolności uzewnętrzniania religii (art. 53 ust. 5) i prawa do informacji o działalności organów władzy publicznej (art. 61 ust. 3). Przepisy Konstytucji RP nakładają także na władzę publiczną obowiązek prowadzenia polityki zapewniającej bezpieczeństwo ekologiczne (art. 74 ust. 1), art. 76 zaś stanowi o konieczności ochrony konsumentów, użytkowników i najemców przed działaniami zagrażającymi bezpieczeństwu.

W pewnych jednak sytuacjach, wymagających działania określonych organów państwa lub samorządów, pojawiają się różnice interpretacyjne dotyczące pojmowania zakresu bezpieczeństwa publicznego. Przykładem może być interpretacja Sądu Najwyższego, który w swojej uchwale wskazał:

działanie „publicznie” zachodzi wówczas, gdy bądź ze względu na miejsce działania, bądź ze względu na okoliczności i sposób działania sprawcy jego zachowanie się jest lub może być dostępne (dostrzegalne) dla ni e określonej li c z by os ób, przy czym sprawca mając świadomość tej możliwości co najmniej na to się godzi. Z kolei miejsce jest publiczne, jeżeli jest dostępne bez specjalnego zezwolenia bliżej nieokreślonemu kręgowi osób. Znamię „publicznie” wskazuje nie tyle na miejsce, ile na sytuację, której jednak nie należy traktować in abstracto, lecz in concreto. Choć zazwyczaj zachowanie w miejscu publicznym ma charakter publiczny, to jednak może być inaczej, na przykład w przypadku dokonania czynu na całkowicie pustej ulicy czy popełnienie go nocą, w odludnym miejscu, w którym nikogo nie było. Może być również tak, że zachowanie sprawcy w miejscu, które nie jest publiczne, będzie jednak miało charakter publiczny (na przykład wypowiedź w studiu telewizyjnym w trakcie audycji „,na żywo") ${ }^{5}$.

${ }^{5}$ Uchwała Sądu Najwyższego z dnia 20 września 1973 r., VI KZP 26/73, OSNKW 1973, nr 11, s. 132. 
Pojęcie „bezpieczeństwo publiczne”, choć używane przez ustawodawcę, nie zostało jednak prawnie zdefiniowane i nie ma legalnej definicji w przepisach prawa. Ustawodawca określił jedynie desygnaty tego pojęcia, a definicji i interpretacji należy szukać w doktrynie i orzecznictwie sądowym, które w tym przypadku są pomocne w stosowaniu prawa. Dodatkowo „bezpieczeństwo publiczne” występuje jako zadanie podmiotów prywatnych (firm ochrony osób i mienia, służb porządkowych angażowanych przez organizatorów imprez masowych) zadanie organizacji i instytucji społecznych oraz obywateli, a także jako przesłanka uzasadniająca cofnięcie określonych uprawnień.

Przyczyną problemów definicyjnych jest między innymi dynamika życia społecznego: pojawiają się nowe niebezpieczeństwa, zmienia się prawo, zmienia się moralność i etyka, a elementy te wpływają na kształtowanie bezpieczeństwa publicznego. Wspólnym mianownikiem wszystkich koncepcji i definicji bezpieczeństwa publicznego jest wskazanie, że poczucie bezpieczeństwa to podstawowa potrzeba każdego społeczeństwa i pojedynczego człowieka. Bez poczucia bezpieczeństwa nie można realizować potrzeb wyższych. Podstawowym zadaniem państwa jest tworzenie, a następnie doskonalenie systemu bezpieczeństwa, aby eliminować wszelkiego typu zagrożenia ${ }^{6}$.

\section{ZADANIA ORGANÓW PAŃSTWA W ZAKRESIE BEZPIECZEŃSTWA PUBLICZNEGO}

Celem systemu bezpieczeństwa i porządku publicznego jest zapobieganie zamachom na życie, zdrowie i mienie polskich obywateli i innych osób przebywających na terytorium RP oraz na interesy państwa oraz ściganie ich sprawców. Jest on tworzony przez organy władzy publicznej, służby, straże i inspekcje wyspecjalizowane w ochronie bezpieczeństwa i porządku publicznego. Jest to zarazem sektor, w którym występuje — oprócz podsystemu ratownictwa medycznego - częściowa prywatyzacja zadań wcześniej realizowanych wyłącznie przez państwo. Zadania organów władzy publicznej w zakresie bezpieczeństwa i porządku publicznego są określone w odpowiednich ustawach, w tym między innymi o służbach specjalnych ${ }^{7}$, Policji ${ }^{8}$, Straży Granicznej ${ }^{9}$, Służbie Celnej ${ }^{10}$ i Biurze Ochrony Rządu ${ }^{11}$. Te i wiele innych instytucji, których bezpośrednim lub też po-

${ }^{6}$ E. Trojan, Bezpieczeństwo i porządek publiczny w Rzeczypospolitej Polskiej w świetle powszechnie obowiązujących przepisów prawa, Rzeszów 2015, s. 399.

${ }^{7}$ Ustawa z dnia 9 czerwca 2006 r. o Służbie Kontrwywiadu Wojskowego oraz Służbie Wywiadu Wojskowego, Dz.U. 2006 r. Nr 104, poz. 709.

8 Ustawa z dnia 6 kwietnia 1990 r. o Policji, Dz.U. 1990 r. Nr 30, poz. 179.

9 Ustawa z dnia 12 października 1990 r. o Straży Granicznej, Dz.U. 1990 r. Nr 78, poz. 462.

10 Ustawa z dnia 27 sierpnia 2009 r. o Służbie Celnej, Dz.U. Nr 168, poz. 1323.

11 Ustawa z dnia 16 marca 2001 r. o Biurze Ochrony Rządu, Dz.U. 2004 r. Nr 163, poz. 1712. 
średnim zadaniem jest ochrona bezpieczeństwa publicznego, niestety nie tworzy w pełni ustrukturyzowanego systemu.

Bezpieczeństwo publiczne to zadanie administracji rządowej oraz samorządowej. Zgodnie z art. 7 ust. 1 pkt 14 ustawy z 8 grudnia 1990 r. o samorządzie gminnym $^{12}$ gmina ma obowiązek zaspokajania zbiorowych potrzeb wspólnoty, co jest jej zadaniem własnym, a zadanie to obejmuje w szczególności sprawy porządku i bezpieczeństwa obywateli oraz ochrony przeciwpożarowej i przeciwpowodziowej, w tym wyposażenia i utrzymania gminnego magazynu przeciwpowodziowego. Dodatkowo zadania te gmina może wykonywać jako zadania zlecone z zakresu administracji rządowej.

Powiat, w myśl art. 4 ust. 1 pkt 15 ustawy z 5 czerwca 1998 r. o samorządzie powiatowym ${ }^{13}$, wykonuje określone ustawami zadania publiczne o charakterze ponadgminnym $\mathrm{w}$ zakresie bezpieczeństwa obywateli. Jako jednostki samorządów lokalnych mają one za zadanie organizować działania w zakresie bezpieczeństwa i porządku publicznego na administrowanym terenie, a także koordynować współdziałanie podległych im gmin.

Samorząd województwa zaś, zgodnie z art. 14 ust. 1 pkt 14 ustawy z dnia 5 czerwca 1998 r. o samorządzie województwa ${ }^{14}$, wykonuje zadania o charakterze wojewódzkim w zakresie bezpieczeństwa publicznego. Utrzymywanie bezpieczeństwa publicznego jest także ustawowo określonym zadaniem wojewody (art. 22 pkt 2 ustawy z dnia 23 stycznia 2009 r. o wojewodzie i administracji rządowej w województwie ${ }^{15}$ ).

Szczególną uwagę przy rozpatrywaniu potencjału bezpieczeństwa narodowego należy zwrócić na zarządzanie kryzysowe. W modelu polskim sytuacja kryzysowa obejmuje jedynie zagrożenia o charakterze niemilitarnym, mimo że zarówno w stanach nadzwyczajnych, jak i w czasie wojny zarządzanie kryzysowe wciąż jest realizowane. Zarządzanie kryzysowe w Polsce na szczeblu centralnym sprawuje Rada Ministrów, korzystając z pomocy rządowego zespołu zarządzania kryzysowego. W województwie zarządzanie kryzysowe sprawują wojewodowie, z wykorzystaniem wojewódzkich zespołów i centrów zarządzania kryzysowego. W samorządzie terytorialnym zarządzanie kryzysowe sprawują: w powiecie starosta, a w gminie - wójt, burmistrz, prezydent miasta, także z wykorzystaniem odpowiednich zespołów i centrów zarządzania kryzysowego.

Utrzymywanie bezpieczeństwa publicznego, jego ochrona oraz zapobieganie zagrożeniom bezpieczeństwa jest podstawową funkcją Policji, zgodnie $\mathrm{z}$ art. 1 ust. 1 ustawy o Policji.

Zagrożenia bezpieczeństwa publicznego można zdefiniować jako ciąg zdarzeń, które wpływają negatywnie na funkcjonowanie organów administracji pań-

12 Dz.U. 1990 r. Nr 16, poz. 95.

13 Dz.U. 1998 r. Nr 91, poz. 578.

14 Dz.U. 1998 r. Nr 91, poz. 576.

15 Dz.U. 2009 r. Nr 31, poz. 206. 
stwowej, jakość życia społeczeństwa czy środowisko naturalne. Zagrożenia te są elementem zagrożeń regionalnych i lokalnych, którymi są sytuacje, konfliktowe i niekonfliktowe, mogące doprowadzić do zerwania lub naruszenia więzi społecznych, gospodarczych i politycznych w skali gminy, powiatu lub województwa. Przeciwdziałanie im leży w kompetencji władz szczebla gminy, powiatu lub województwa ${ }^{16}$. Tworzenie warunków zapobiegających zagrożeniom jest więc jednym z zadań wszystkich organów państwa nałożonych na nich w odpowiednich regulacjach prawnych.

\section{BEZPIECZEŃSTWO IMPREZ MASOWYCH}

Imprezy masowe mają szczególny charakter ze względu na skupianie dużej liczby uczestników na konkretnie do tego przeznaczonym terenie, co wiąże się ze zwiększeniem ryzyka wystąpienia zagrożeń oraz zakłócenia stanu bezpieczeństwa i porządku publicznego. W celu umożliwienia skutecznego i sprawnego działania, wprowadzenia zasad postępowania koniecznych do zapewnienia bezpieczeństwa, mechanizmów wydawania zezwolenia oraz egzekwowania prawa przez podmioty biorące udział w zabezpieczaniu imprezy masowej (organizator, służby porządkowe i informacyjne, władze samorządowe, Policja, Państwowa Straż Pożarna, służby medyczne itp.) wprowadzono rozwiązania systemowe, które stoją na straży bezpieczeństwa imprez masowych.

Impulsem do podjęcia działań legislacyjnych w zakresie bezpieczeństwa imprez masowych stały się tragiczne wydarzenia na stadionach piłkarskich w latach 80. XX w. ${ }^{17} \mathrm{~W}$ reakcji na te wydarzenia Rada Europy opracowała Europejską konwencję nr $120 \mathrm{w}$ sprawie przemocy i ekscesów widzów w czasie imprez sportowych, a w szczególności meczów piłki nożnej, którą podpisano 19 sierpnia 1985 r. w Strasburgu ${ }^{18}$.

16 Więcej na ten temat B. Bonisławska, Wspótczesne zagrożenia dla bezpieczeństwa publicznego, Lublin 2012, s. 113-128.

17 W Wielkiej Brytanii, w Bradford, 11 maja 1985 r. w trakcie meczu na trybunach stadionu wybuchł pożar, w którym zginęło 56 widzów, a 265 zostało poparzonych. Niespełna dwa tygodnie później, 29 maja 1985 r., na stadionie Heysel w Brukseli w czasie meczu finałowego Pucharu Europy doszło z kolei do zamieszek między kibicami drużyn FC Liverpool i Juventus Turyn. W wyniku starć zginęło 39 osób, a ponad 400 zostało rannych.

18 Europejska konwencja w sprawie przemocy i ekscesów widzów w czasie imprez sportowych, a w szczególności meczów piłki nożnej, sporządzona w Strasburgu dnia 19 sierpnia 1985 r., Dz.U. $1995 \mathrm{Nr}$ 129, poz. 625. Konwencja miała na celu przede wszystkim zapobieganie i kontrolowanie aktów przemocy i wybryków widzów podczas imprez sportowych, między innymi przez zatrudnienie wykwalifikowanych służb porządkowych zajmujących się ochroną bezpieczeństwa i porządku zarówno na stadionie, jak i wzdłuż tras dojazdowych. Służby miały odpowiadać za skuteczną kontrolę osób na bramkach wejściowych, a w szczególności niedopuszczenie do wnoszenia na teren stadionu narzędzi niebezpiecznych, środków odurzających oraz napojów alkoholowych. 
W Polsce rezultatem pilnych działań legislacyjnych była ustawa z 22 sierpnia 1997 r. o bezpieczeństwie imprez masowych ${ }^{19}$. Przepisy ustawy określały uprawnienia i obowiązki organizatora imprezy masowej, procedurę wydawania zezwoleń na przeprowadzenie przedsięwzięcia, warunki bezpieczeństwa imprezy masowej, zasady odpowiedzialności za szkody powstałe $\mathrm{w}$ trakcie trwania imprezy oraz $\mathrm{w}$ związku $\mathrm{z}$ jej organizacją, a także za działania niezgodne z ustawą. Ustawa nakładała też na uczestników imprezy masowej nakaz przestrzegania regulaminu wydarzenia oraz odpowiednie zachowanie, które nie narusza bezpieczeństwa pozostałych osób. Wprowadzono kilka nowych procedur, które miały służyć utrzymaniu bezpieczeństwa i porządku na stadionach. Był to na przykład zakaz stadionowy czy obowiązek identyfikacji uczestników podczas niektórych rodzajów imprez masowych (masowa impreza sportowa).

W 2008 r. rozpoczęto pracę nad nowym aktem prawnym regulującym kwestię bezpieczeństwa imprez masowych, aby zapewnić odpowiednie warunki porządku publicznego w czasie Mistrzostw Europy w Piłce Nożnej UEFA Euro 2012. Ustawa z dnia 20 marca 2009 r. o bezpieczeństwie imprez masowych ${ }^{20}$ w porównaniu z poprzednią, zawiera znacznie bardziej rozbudowany katalog wykroczeń i przestępstw. Ustawa zgodnie $\mathrm{z}$ art. 1 określa: zasady postępowania konieczne do zapewnienia bezpieczeństwa imprez masowych; warunki bezpieczeństwa imprez masowych; zasady i tryb wydawania zezwoleń na ich przeprowadzanie; zasady gromadzenia i przetwarzania informacji dotyczących ich bezpieczeństwa; oraz zasady odpowiedzialności organizatorów za szkody wyrządzone w związku ze zorganizowaniem imprez masowych.

Ustawa wyróżnia dwa rodzaje imprez masowych: imprezy artystyczno-rozrywkowe oraz imprezy sportowe, do których wlicza się między innymi mecze piłki nożnej. Nie definiuje jednak pojęcia „impreza”. Zgodnie z potocznym rozumieniem tego terminu ,impreza” to koncert, zawody sportowe itp. organizowane w celach rozrywkowych, zabawa, spotkanie towarzyskie, przedsięwzięcie, zamysł. W art. 3 pkt 1 ustawodawca zdefiniował zaś pojęcie imprezy masowej, przez którą należy rozumieć imprezę masową artystyczno-rozrywkową, masową imprezę sportową, w tym mecz piłki nożnej, $\mathrm{z}$ wyjątkami wymienionymi w tym artykule.

Zgodnie z art. 3 pkt 2 ustawy przez imprezę masową artystyczno-rozrywkową należy rozumieć imprezę o charakterze artystycznym, rozrywkowym lub zorganizowane publiczne oglądanie przekazu telewizyjnego na ekranach lub urządzeniach umożliwiających uzyskanie obrazu o przekątnej przekraczającej $3 \mathrm{~m}$, która ma się odbyć:

Konwencja wskazała też na potrzebę ograniczenia lub całkowitego zakazu sprzedaży i rozprowadzania napojów alkoholowych na stadionach. Ponadto sygnatariusze zobowiązali się do dostosowania własnych przepisów do jej wymogów oraz do ciągłych prac nad poprawą infrastruktury stadionowej.

19 Dz.U. 1997 r. Nr 106, poz. 680.

${ }^{20}$ Dz.U. Nr 62, poz. 504 (dalej: u.b.i.m.). 
a) na stadionie, w innym obiekcie niebędącym budynkiem lub na terenie umożliwiającym przeprowadzenie imprezy masowej, na których liczba udostępnionych przez organizatora miejsc dla osób, ustalona zgodnie z przepisami prawa budowlanego oraz przepisami dotyczącymi ochrony przeciwpożarowej, wynosi nie mniej niż tysiąc,

b) w hali sportowej lub w innym budynku umożliwiającym przeprowadzenie imprezy masowej, w których liczba udostępnionych przez organizatora miejsc dla osób, ustalona zgodnie z przepisami prawa budowlanego oraz przepisami dotyczącymi ochrony przeciwpożarowej, wynosi nie mniej niż pięćset.

Natomiast masowa impreza sportowa, zgodnie z art. 3 pkt 3 ustawy, ma na celu współzawodnictwo sportowe lub popularyzowanie kultury fizycznej, organizowana na:

a) stadionie lub innym obiekcie niebędącym budynkiem, na którym liczba udostępnionych przez organizatora miejsc dla osób, ustalona zgodnie z przepisami prawa budowlanego oraz przepisami dotyczącymi ochrony przeciwpożarowej, wynosi nie mniej niż tysiąc, a w przypadku hali sportowej lub innego budynku umożliwiającego przeprowadzenie imprezy masowej - nie mniej niż trzysta,

b) terenie umożliwiającym przeprowadzenie imprezy masowej, na którym liczba udostępnionych przez organizatora miejsc dla osób wynosi nie mniej niż tysiąc.

Mecz piłki nożnej został uznany przez ustawodawcę za rodzaj masowej imprezy sportowej, mającej na celu współzawodnictwo w piłce nożnej, organizowanej na stadionie lub innym obiekcie sportowym, na którym liczba udostępnionych przez organizatora miejsc dla osób, ustalona zgodnie z przepisami prawa budowlanego oraz przepisami dotyczącymi ochrony przeciwpożarowej, wynosi nie mniej niż tysiąc.

W świetle ustawy na szczególną uwagę zasługuje instytucja zakazu klubowego. Zgodnie z art. 14 ustawy organizator meczu piłki nożnej może stosować zakaz klubowy, polegający na zakazie uczestniczenia w kolejnych imprezach masowych przeprowadzanych przez organizatora meczu piłki nożnej, nakładany przez tego organizatora na osobę, która dopuściła się naruszenia regulaminu obiektu (terenu) lub regulaminu imprezy masowej. Zakaz klubowy dotyczy też kolejnych imprez masowych przeprowadzanych $\mathrm{z}$ udziałem drużyny organizatora rozgrywanych poza siedzibą organizatora i może być nakładany za naruszenie regulaminu obiektu (terenu) lub regulaminu imprezy masowej prowadzonej z udziałem drużyny tego organizatora. Okres obowiązywania zakazu klubowego nie może być dłuższy niż dwa lata (a w szczególnych przypadkach nawet sześć lat) od dnia jego wydania.

Przepis art. 5 ustawy ustanawia ogólną odpowiedzialność organizatora imprezy masowej za bezpieczeństwo. Bezpieczeństwo imprezy masowej obejmuje spełnienie przez organizatora wymogów w zakresie: zapewnienia bezpieczeństwa osobom uczestniczącym w imprezie; ochrony porządku publicznego; zabezpieczenia pod względem medycznym oraz zapewnienia odpowiedniego stanu tech- 
nicznego obiektów budowlanych wraz ze służącymi tym obiektom instalacjami i urządzeniami technicznymi, w szczególności przeciwpożarowymi i sanitarnymi (art. 5 ust. 2).

W świetle ustawy organizatorem jest osoba prawna, osoba fizyczna lub jednostka organizacyjna nieposiadająca osobowości prawnej, przeprowadzająca imprezę masową. Zorganizowanie imprezy masowej może mieć miejsce także przy udziale kilku podmiotów. Zastosowanie w definicji liczby pojedynczej organizatora imprezy masowej (określonej w art. 3 pkt 9) nie oznacza, że ustawodawca zabronił zorganizowania na przykład widowiska sportowego przez kilka podmiotów. Ustawa w art. 6 ust. 1 wymienia przy tym katalog obowiązków organizatora imprezy masowej.

Zgodnie z art. 5 ust. 5 ustawy za bezpieczeństwo imprezy w miejscu i czasie jej trwania odpowiada wyłącznie jej organizator. Przepis ten kreuje między innymi zobowiązanie o charakterze gwarancyjnym. Jego niewypełnienie powoduje odpowiedzialność organizatora imprezy masowej. Ustawodawca przeniósł tym samym ciężar zapewnienia bezpiecznej imprezy masowej na organizatora imprezy ${ }^{21}$. Potwierdzone to zostało w orzecznictwie — z jednoznacznego brzmienia art. 5 ust. 1 ustawy wynika, że „organizator imprezy masowej jest obowiązany do zapewnienia bezpieczeństwa osobom obecnym na imprezie oraz porządku podczas trwania imprezy"22. W innym wyroku wskazano, iż

przepis ten oznacza, że cały ciężar odpowiedzialności za bezpieczeństwo imprezy masowej spoczywa na jej organizatorze, nawet jeżeli powierzył on dbałość o bezpieczeństwo imprezy wyspecjalizowanej jednostce trudniącej się zawodowo ochroną osób i mienia ${ }^{23}$.

\section{Wskazano ponadto, iż}

nie budzi wątpliwości, że prowadzenie klubu nocnego i organizowanie w nim dyskotek wyczerpuje pojęcie imprezy masowej. Jedynym kryterium wynikającym z art. 3 pkt 1 ustawy jest, aby liczba miejsc na imprezie rozrywkowej w budynku, w którym impreza jest organizowana wynosiła nie mniej niż 300 osób. Nawet gdyby ustalono, że imprezy organizowane przez pozwanego nie miały statusu imprezy masowej, to i tak błędne było założenie, iż warunkiem koniecznym dla przyjęcia odpowiedzialności pozwanego było wykazanie, że sprawcą uszkodzenia ciała była osoba zatrudniona przez pozwanego w charakterze pracownika ochrony. [...] Osoba prowadząca lokal nocny i organizująca dyskoteki jest bowiem zobowiązana do zapewnienia podwyższonego standardu bezpieczeństwa, w tym zminimalizowania ryzyka występowania na tego typu imprezach rozmaitych aktów przemocy. $Z$ obowiązku tego wynika konieczność zatrudnienia odpowiedniej ilości pracowników obsługi lokalu, w tym odpowiedzialnych za bezpieczeństwo osób biorących udział w imprezie ${ }^{24}$.

${ }^{21}$ M. Dróżdż, Ustawa o bezpieczeństwie imprez masowych. Komentarz, Warszawa 2015, s. 67.

22 Wyrok Sądu Okręgowego w Gdańsku z dnia 6 maja 2011 r., III Ca 1611/10, LEX nr 1713685.

23 Wyrok Sądu Najwyższego - Izba Cywilna z dnia 26 września 2003 r., IV CK 8/2002, OSNC 2004/11, poz. 180.

${ }^{24}$ Ibidem. 
Wskazać należy, iż informacje o przewidywanych zagrożeniach bezpieczeństwa i porządku publicznego oraz sposobie identyfikacji uczestników imprezy masowej powinny znaleźć się we wniosku o wydanie zezwolenia na przeprowadzenie imprezy masowej (art. 26 pkt 4 i 6 ustawy). Choć ustawa nie definiuje pojęcia „uczestnik imprezy”, to określa obowiązki osób uczestniczących w imprezie masowej. W doktrynie prawa wskazano, że „każda osoba, która przebywa na terenie imprezy masowej jest jej uczestnikiem [...]. Część komentatorów uważa, że uczestnik to osoba mająca ważny bilet lub inny dokument uprawniający do przebywania na imprezie masowej. Jeszcze inni wskazują, że uczestnikiem jest osoba, która uczestniczy w imprezie masowej. Część komentatorów podaje, że uczestnikiem imprezy masowej, a tym samym tej sportowej, jest 'widz"'25. W ocenie M. Dróżdża uczestnikiem imprezy masowej jest każda osoba, która uczestniczy w imprezie masowej. Uczestnikami takimi będą też zawodnicy klubu piłkarskiego, którzy aktywnie biorą udział we współzawodnictwie sportowym podczas imprezy masowej. Takimi podmiotami będą też osoby, które mimo że nie są pracownikami klubu ani kibicami, uczestniczą na przykład w relacjonowaniu imprezy masowej (na przykład kamerzysta stacji telewizyjnej) ${ }^{26}$.

Zgodnie $\mathrm{z}$ art. 8 ustawy osoby uczestniczące $\mathrm{w}$ imprezie masowej są obowiązane zachowywać się w sposób niezagrażający bezpieczeństwu innych osób, a w szczególności przestrzegać postanowień regulaminu obiektu (terenu) i regulaminu imprezy masowej. Zabrania się wnoszenia na imprezę masową i posiadania przez osoby w niej uczestniczące broni lub innych niebezpiecznych przedmiotów, materiałów wybuchowych, wyrobów pirotechnicznych, materiałów pożarowo niebezpiecznych, napojów alkoholowych, środków odurzających lub substancji psychotropowych.

Organizator udostępnia osobom uczestniczącym w imprezie masowej regulamin obiektu (terenu) oraz opracowuje i udostępnia tym osobom regulamin imprezy masowej zawierający warunki uczestnictwa i zasady zachowania się osób na niej obecnych. Zgodnie z art. 3 pkt 10 u.b.i.m. przez regulamin obiektu rozumie się przepisy zawierające zasady wstępu na teren obiektu, w tym osób małoletnich, zasady zachowania się osób obecnych w obiekcie i korzystania przez nie z obiektu oraz ze znajdujących się tam urządzeń, a także określające miejsca nieprzeznaczone dla publiczności. Regulamin imprezy masowej powinien zaś zawierać warunki uczestnictwa w takiej imprezie oraz zasady zachowania się osób na niej obecnych (art. 6 ust. 3). Regulamin obiektu i regulamin imprezy masowej zawierają więc między innymi przepisy kształtujące prawa i obowiązki uczestników imprezy masowej.

Zgodnie $\mathrm{z}$ art. 8 ust. 1 , art. 22 ust. 1 pkt 2 i art. 54 ust. 1 u.b.i.m. uczestnik imprezy masowej obowiązany jest znać postanowienia regulaminu obiektu, w którym się ona odbywa. Prowadzi to do wniosku, że jeżeli organizator imprezy

${ }^{25}$ M. Dróżdż, op. cit., s. 31.

26 Ibidem. 
masowej, zawierający — na podstawie wzorca umowy — z jej przyszłymi uczestnikami umowy zapewniające im udział w imprezie, zamieścił regulamin imprezy lub regulamin obiektu we wzorcu umowy, to w zakresie, w jakim regulaminy te kształtują prawa i obowiązki konsumenta jako strony umowy — kontrahenta organizatora imprezy, stanowią one wzorzec umowy w rozumieniu art. 384 k.c. i podlegają ocenie według kryteriów przewidzianych w art. $385^{1}$ i n. k.c.

Zadania związane z zapewnieniem bezpieczeństwa i porządku publicznego w czasie trwania imprezy masowej realizowane są przez członków służby porządkowej i informacyjnej. Zgodnie z dyspozycją zawartą w pkt 12 art. 3 ustawy służbę informacyjną stanowią osoby (w tym spiker zawodów sportowych), które działają na rzecz bezpieczeństwa uczestników imprezy masowej, w szczególności przez informowanie ich o przyjętych rozwiązaniach organizacyjnych (art. 19 pkt 2). Służba porządkowa to osoby wyznaczone przez organizatora, legitymujące się ważną licencją pracownika ochrony fizycznej, o której mowa w art. 26 lub 27 ustawy z 22 sierpnia 1997 r. o ochronie osób i mienia ${ }^{27}$, działające na rzecz bezpieczeństwa i porządku publicznego w czasie i w miejscu trwania imprezy masowej.

Zgodnie z art. 26 ust. 1 pkt 5 do wniosku o wydanie zezwolenia na przeprowadzenie imprezy masowej należy dołączyć następujące dane: imię, nazwisko, numer PESEL, numer i datę wydania zaświadczenia o ukończeniu kursu dla kierowników do spraw bezpieczeństwa imprez masowych, a w przypadku imprezy masowej podwyższonego ryzyka dodatkowo numer i datę wydania licencji pracownika ochrony fizycznej drugiego stopnia. Ustawa obliguje organizatora do zapewnienia minimalnej liczby członków służby porządkowej oraz informacyjnej.

W doktrynie prezentuje się stanowisko, że kierownik ds. bezpieczeństwa ze względu na fakt, że nie został przez ustawodawcę zakwalifikowany jako członek służby porządkowej lub informacyjnej, mimo formalnego kierowania tymi służbami nie jest uprawniony do wydawania poleceń porządkowych uczestnikom imprezy masowej. Może wydawać polecania służbowe członkom podległej mu służby ${ }^{28}$.

Organizator odpłatnej imprezy masowej zobowiązany jest do zawarcia umowy ubezpieczenia od odpowiedzialności cywilnej za szkody wyrządzone osobom w niej uczestniczącym. Jest to bardzo rozsądne rozstrzygnięcie, gdyż ułatwia poszkodowanym w takiej imprezie dochodzenie odszkodowania. Jednocześnie zaś zabezpiecza podmiot organizujący imprezę. Oprócz tego organizator imprezy masowej, na którą wstęp jest odpłatny, odpowiada za szkody obejmujące równowartość zniszczonego lub uszkodzonego mienia, jakie poniosły służby (Policja, Żandarmeria Wojskowa, straż gminna (miejska), Państwowa Straż Pożarna i inne jednostki ochrony przeciwpożarowej oraz służba zdrowia), w związku z ich działaniami w miejscu i w czasie trwania imprezy masowej. Organizator odpowiada po przedstawieniu przez te organy dokumentów przedstawiających zakres szkód.

27 Dz.U. 1997 r. Nr 114, poz. 740.

28 C. Kąkol, Bezpieczeństwo imprez masowych. Komentarz, Warszawa 2012. 
Zakres ubezpieczenia, termin powstania obowiązku ubezpieczenia oraz minimalną sumę gwarancyjną, zważywszy na rodzaj szkód mogących wystąpić w związku z planowaną imprezą, reguluje rozporządzenie Ministra Finansów z dnia 11 marca 2010 r. w sprawie obowiązkowego ubezpieczenia odpowiedzialności cywilnej organizatorów imprez masowych ${ }^{29}$. Ubezpieczeniem OC jest objęta odpowiedzialność cywilna organizatorów imprez masowych, na które wstęp jest odpłatny, za szkody wyrządzone w okresie trwania ochrony ubezpieczeniowej, w następstwie działania lub zaniechania ubezpieczonego, osobom w nich uczestniczącym. W przypadku imprezy nieodpłatnej organizator, mimo że bierze na siebie odpowiedzialność za osoby przebywające na terenie imprezy, nie ma obowiązku wykupienia ubezpieczenia od odpowiedzialności cywilnej. Wydaje się, że niezależnie od tego, czy taki obowiązek przewiduje ustawa, wszystkie tego typu imprezy powinny być jednak ubezpieczane, ponieważ obarczone są wysokim ryzykiem.

Ustawa o bezpieczeństwie imprez masowych określa dość rozległy zakres kar za nieprzestrzeganie jej przepisów. Rozdział 9 ustawy specyfikuje sankcje karne za określone wystąpienia zakłóceń porządku i zagrożeń bezpieczeństwa. Do większości wymienionych w ustawie wykroczeń i przestępstw zastosowany może być tryb przyspieszony postępowania, który regulują przepisy kodeksu postępowania w sprawach o wykroczeniach lub kodeksu postępowania karnego.

\section{PODSUMOWANIE}

Przedstawiony w artykule przegląd regulacji prawnych dotyczących bezpieczeństwa publicznego, ze szczególnym uwzględnieniem bezpieczeństwa imprez masowych, pokazuje ewolucję tych regulacji wraz z dynamicznie zmieniającymi się różnorakimi warunkami organizowania wszelkich imprez masowych, nie tylko sportowych. Wydarzenia ostatnich miesięcy w Europie i na świecie, związane z masowymi migracjami ludności i terroryzmem, wskazują na potrzebę ciągłego i systematycznego szukania umocowanych prawnie doskonalszych metod zapobiegania zagrożeniom bezpieczeństwa publicznego.

Należy podkreślić, że w doktrynie prawa wskazuje się na konieczność dokonania zmian w ustawie o bezpieczeństwie imprez masowych. M. Dróżdż stwierdza między innymi, że na aprobatę zasługuje propozycja dookreślenia odpowiedzialności organizatora imprezy masowej. W doktrynie występuje jednolite stanowisko co do odpowiedzialności karnej oraz administracyjnej tego podmiotu. Wiele miejsca poświęca się określeniu zakresu jego odpowiedzialności cywilnej. Sprawa wskazanej odpowiedzialności cywinej znalazła finał w Sądzie Najwyższym, który w wyroku stwierdził, że odpowiedzialność cywilna organizatora ma charakter absolutny — organizator odpowiada za wszystko, co wydarzy się w trakcie imprezy

29 Dz.U. 2010 r. Nr 54, poz. 323. 
masowej. Trudno zgodzić się z takim poglądem, dlatego też wydane orzeczenie spotkało się z krytyką. Artykuł 5 ust. 1 u.b.i.m. stanowi, iż organizator odpowiada za bezpieczeństwo imprezy masowej w miejscu i czasie jej trwania. Część komentatorów wskazuje, iż przepis ten kreuje „szczególną” odpowiedzialność organizatora imprez masowych za jakiekolwiek zdarzenia mogące wpłynąć negatywnie na bezpieczeństwo uczestników imprezy, na przykład widzów meczu piłki nożnej, nawet $\mathrm{w}$ przypadku powierzenia czynności przedsiębiorcy, który wykonuje je w zakresie swej działalności zawodowej. Dlatego też Sąd Najwyższy stwierdził w wyroku, że przepis ten stanowi lex specialis w stosunku do art. 429 k.c., co oznacza, że zwolnienie organizatora $\mathrm{z}$ odpowiedzialności ze względu na treść art. 5 u.b.i.m. jest w znacznym stopniu ograniczone, a w pewnych wypadkach wręcz niemożliwe. Wskazane byłoby więc ustalenie w u.b.i.m., że przepis art. 5 u.b.i.m., wyłącza możliwość zastosowania na przykład art. 429 k.c. I ta kwestia wymaga de lege ferenda ingerencji ustawodawcy ${ }^{30}$.

\section{SELECTED ASPECTS OF THE LEGAL SECURITY OF MASS EVENTS}

\section{Summary}

The article presents some aspects of the legal system in Poland relating generally to the complex issues of security, and in particular to the specific - due to the form and features of occurrence - security of mass events. Starting from the existing literature in terms of security and public safety, the article discusses the constitutional and statutory regulations, including those related to them, some interpretations and case law, with particular reference to the law on mass events security.

30 M. Dróżdż, Potrzeba zmiany ustawy o bezpieczeństwie imprez masowych. Praktyczne problemy z jej zastosowaniem - wybrane zagadnienia, „Ius Novum” 2014, nr 3; idem, Glosa do wyroku Sądu Najwyższego z dnia 19 października 2012 r., IV CSK 439/11, „Ius Novum” 2013, nr 2. 